Food, Dairy and Home Economic Research

http:/www.journals.zu.edu.eg/journalDisplay.aspx?Journalld=1\&queryType=Master

\title{
FUNCTIONAL PROPERTIES OF FABA BEAN PROTEIN AND EFFECT OF ENZYMATIC HYDROLYSIS ON ITS ANTIOXIDANT ACTIVITY
}

\author{
Mostafa Ali* \\ Food Technol. Dept., Fac. Agric., Kafrelsheikh Univ., Egypt
}

\section{Received: 14/01/2019 ; Accepted: 10/02/2019}

\begin{abstract}
Protein play an important role in determining structure and texture of various food products. Therefore, the goals of this research were to study the functional properties of faba bean protein cultivar, Giza3, compared to $\beta$-Lactoglobulin $(\beta-\mathrm{Lg})$ and to hydrolyze this protein using pepsin at different $\mathrm{pH}$ values (1.5 and 3$)$ and different incubation periods $(0,5,10,60$, and $180 \mathrm{~min})$ to characterize the resultant hydrolysates and evaluate their antioxidant activities. The solubility at different $\mathrm{pH}$, emulsifying properties, stability against creaming and oil droplets size, of faba bean protein were tested compared to $\beta-\mathrm{Lg}$ protein. The findings cleared that the solubility and emulsifying properties of faba protein were very low compared to $\beta-\mathrm{Lg}$. Concerning to hydrolysis process, the degree of hydrolysis at $\mathrm{pH} 1.5$ was higher than that at $\mathrm{pH} 3$. The molecular weight distribution bands of faba protein hydrolysates were in the range of 9-98 $\mathrm{kDa}$ using SDS-PAGE method while, peptides were in the range of $500-4000$ Da using MALDI-TOF MS method. The results of both methods confirmed that the hydrolysis at $\mathrm{pH} 1.5$ was higher than $\mathrm{pH} 3$. Moreover, the enzymatic hydrolysis significantly improved the antioxidant activity of faba bean protein. Hydrolysates produced at $\mathrm{pH} 3$ had a slight high antioxidant activity than at $\mathrm{pH} 1.5$ at all incubation periods. Finally, these results suggest that faba bean hydrolysates could be used in preparing functional foods and as natural antioxidants to prevent oxidation process in food products.
\end{abstract}

Key words: Faba bean protein, functional properties, enzymatic hydrolysis, SDS-PAGE, MALDITOF MS, antioxidant activity.

\section{INTRODUCTION}

Faba bean (FB), also known as Vicia faba, fava bean or broad bean, is a flowering plant in the family of Fabaceae and genus of Vicia. In Egypt, the cultivated area and amount of production of faba beans decreased from 221000 faddan and 413 tons in year 2005 to 88000 faddan and 142 tons in 2016 (Egyptian Ministry of Agriculture and Land Reclamation, the Economic affairs Sector). It is one of the main sources of inexpensive protein in Africa, Latin America and parts of Asia (Haciseferogullari et al., 2003). $7 \mathrm{~S}$ and $11 \mathrm{~S}$ globulins, albumins and glutelins are the main fractions of FB proteins (Hossain and Mortuza, 2006; Kimura et al., 2008). When the anti-nutritional factors content is low in the
FB meal, it could be used well as a good source for amino acids, especially lysine, for supplementing the cereals and for feeding the laying hens (El-Fiel et al., 2002; Magoda and Gous, 2011). The FB protein isolate showed the lowest solubility at a range of $\mathrm{pH}$ from 4 to 6 , while it showed the highest solubility at $\mathrm{pH} 8$ and 9 (Fernández-Quintela et al., 1997).

Although several animal proteins showed excellent organoleptic and functional properties, unluckily, they require a high production cost compared to plant proteins. The problem is that the functionality of plant protein is often unsatisfactory due to the low solubility in aqueous media. Several studies evaluated the functionality of plant proteins (chickpeas, lupins, lentils, ... etc.) (Bamdad et al., 2006;

${ }^{*}$ Corresponding author: Tel. : +201013678465

E-mail address: mostafa.ali@agr.kfs.edu.eg 
Morales-De Leon et al., 2007). Enzymatic hydrolysis intensively improves the solubility of proteins and modifies their functional properties, depending on three main structural changes: a reduction of mole mass, a greater availability of hydrophobic regions and the release of ionizable groups. The enzymatic hydrolysis was done on the protein of Red Tilapia fish using thermolysin and alcalase enzymes under optimum conditions. The results showed that both enzymatic hydrolysates yielded an increase in peptide content and antioxidant activity (Daud et al., 2013).

Alkali or acid protein hydrolysis compared to enzymatic hydrolysis offers more moderate conditions of the process and few undesirable products. In the enzymatic hydrolysis, the functionality of hydrolysate can be controlled by selection of specific enzymes, which used to break specific peptide bonds, and reaction factors. The resulted peptides have a small molecular size compared to normal proteins. Therefore, their functional properties are changed: improved solubility at different $\mathrm{pH}$ values, reduced viscosity, and noteworthy changes in emulsifying, gelling, and foaming properties (Hrckova et al., 2002).

The functional properties, such as antioxidant activity, of different proteins including soybean and milk have also modified using enzymatic hydrolysis (Le Tien et al., 2001; Hu et al., 2003; Penas et al., 2004; Chove et al., 2007). Therefore, this research was undertaken for four objectives: (i) study the functional properties of faba bean protein compared to $\beta$-Lactoglobulin (ß-Lg) (ii) hydrolysis of faba bean protein using pepsin enzyme and evaluate whether the resultant protein was affected by time and $\mathrm{pH}$ conditions (iii) characterization of protein hydrolysates using RP-HPLC and SDS-PAGE methods in addition to MALDI-TOF MS, and finally (iiii) to determine the antioxidant activity of resulted hydrolysates.

\section{MATERIALS AND METHODS}

\section{Materials}

Faba bean Giza 3 cultivar was obtained from Agriculture Research Center, Institute of Field Crops, Giza, Egypt. ß-Lg powder was bought from Davisco Foods International, Inc. USA. Pepsin (EC 3.4.21.1) was obtained from SigmaAldrich Co. Ltd. Coomassie Brilliant Blue R250 and bovine serum albumin (BSA) were bought from Serva (Heidelberg, Germany), and 2,5-Dihydroxy actetophenone (DHAP) was obtained from Bruker Daltonik $\mathrm{GmbH}$, Germany. The other reagents and chemicals were in an analytical grade.

\section{Methods}

\section{Sample Preparation}

Faba beans were milled by an Ultra Centrifugal Mill ZM 200 (Retsch GmbH, Germany), with a $0.4 \mathrm{~mm}$ mesh ring sieve. The milled samples were kept at $-20^{\circ} \mathrm{C}$ in polyethylene bags till analysis.

\section{Determination of Gross Chemical Composition of Faba Bean}

The chemical composition of FB flour (moisture, protein, fat, fiber, ash, and available carbohydrates calculated by difference) was determined using Near Infrared spectrometry (NIR) (Unity Scientific Co, USA) included InfoStar Software, version 3.11.1 (AOAC, 2011; Wimonsiri et al., 2017).

\section{Extraction of Faba bean Protein}

Faba bean protein was extracted using $0.04 \%$ ascorbic acid solvent as described by Ali $\boldsymbol{e t}$ al. (2012). Two grams of frozen FB flour were placed in $50 \mathrm{ml}$ centrifuge tube. Then $20 \mathrm{ml}$ ascorbic acid (0.04\%) was added. After that, the mixture was stirred at room temperature for 4 hr., and centrifuged at $4100 \times \mathrm{g}$ for twenty minutes, then the clear supernatant was carefully collected, freeze dried. Protein was kept at $-20^{\circ} \mathrm{C}$ in plastic bottles until analysis.

\section{Determination of Protein Content of Extracts}

Protein content was determined according to the method of Bradford (1976) using BSA as a standard.

\section{Functional Properties of Extracted Protein}

\section{Solubility of faba bean protein compared} to $\mathrm{B}-\mathrm{Lg}$ protein

One milligram $\mathrm{FB}$ and $\mathrm{B}-\mathrm{Lg}$ proteins were dissolved in one milligram of sodium phosphate 
buffer $(0.05 \mathrm{M})$ at different $\mathrm{pH}$ values $(2-9)$. Protein solutions were centrifuged at $9250 \times \mathrm{g}$ and $4{ }^{\circ} \mathrm{C}$ for $10 \mathrm{~min}$ and the protein content of supernatants was measured according to the method of Bradford (1976).

\section{Emulsifying Properties of Faba Bean Protein Compared to B-Lg Protein}

\section{Preparation of emulsions}

FB and $\beta-L g$ protein emulsions $(10 \%$ oil in distilled water) were prepared as mentioned by Khalil et al. (2012) with some modifications. $0.2 \%$ protein solution was stirred with the oil at $500 \mathrm{rpm}$ for ten minutes, then the emulsifying process was completed by an ultrasonic homogenizer Sonicator (Bandelin $\mathrm{GmbH}$. Germany) for five minutes.

\section{Oil droplets size of emulsion}

Oil droplets size of emulsions and their distribution were estimated by Malvern Mastersizer S, Germany. The volume weighted mean of oil droplet size D $(4,3)$, the surface weighted mean diameter of oil droplet $\mathrm{D}(3,2)$, and average size of oil droplets $\left(10^{\text {th }}, 50^{\text {th }}\right.$ and $90^{\text {th }}$ percentile of the diameter) were calculated by the software of equipment depending on Mie's theory (Khalil et al., 2012).

\section{Stability of emulsion against creaming}

After homogenization, the stability of emulsions against creaming was measured under centrifugal force as mentioned by Ali et al. (2013) using a spectrophotometer (SPEKOL, Carl Zeiss, Germany).

\section{Enzymatic hydrolysis of faba bean protein}

Enzymatic hydrolysis process was done according to Yang et al. (2011), with slight modifications. Forty grams of FB flour were mixed with $400 \mathrm{ml}$ ascorbic acid (0.04\%). Next, the mixture was stirred at room temperature for $4 \mathrm{hr}$., and centrifuged at $4100 \times \mathrm{g}$ for $20 \mathrm{~min}$, after that the supernatants were carefully collected and the $\mathrm{pH}$ was adjusted with $1 \mathrm{~N} \mathrm{HCl}$ to 1.5 and 3.0 and temperature at $34^{\circ} \mathrm{C}$. Then the pepsin was added, ratio of enzyme to protein was 1:100 $(W / W)$. Samples were removed after $0,5,10,60$ and 180 min and adjusted to $\mathrm{pH}$ 7.58 to inactivate the enzyme. The hydrolysates were then freeze-dried and ground for further analysis.

\section{Degree of hydrolysis}

The degree of hydrolysis (DH) was calculated as the ratio between the content of protein after hydrolysis and the total protein content before hydrolysis (Bradford, 1976).

Determination of free amino groups content of hydrolysates by TNBS method

Trinitrobenzenesulfonic acid (TNBS) method was used to analyze the content of free amino groups in faba bean hydrolysates according to Adler-Nissen (1979). Protein solution (mg/in ml $1 \%$ sodium dodecyl sulfate, SDS) was kept with TNBS substance at $\mathrm{pH} 9$ and $40^{\circ} \mathrm{C}$ for $60 \mathrm{~min}$ then, the absorbance of resulted colour was recorded at $340 \mathrm{~nm}$ by Pharmacia Biotech spectrophotometer, England. Isoleucine in range from 20 to $100 \mathrm{nM}$ was used to prepare the calibration curve.

\section{Determination of protein content of hydrolysates using RP-HPLC}

Reversed phase-high performance liquid chromatography method was used to determine the protein content. Four milligrams of faba protein and hydrolysates were dissolved in one $\mathrm{ml}$ of potassium phosphate (PBS) buffer at $\mathrm{pH}$ 7.2, then analyzed by Shimadzu HPLC system (Kyoto, Japan) using a Perfectsil $300-\mathrm{C} 8$ column $(300 \times 4,6 \mathrm{~mm} ; 5 \mu \mathrm{m})$ at $50^{\circ} \mathrm{C}$. HPLC grade water containing $0.1 \% \quad(V / V)$ triflouroacetic acid (TFA) was the eluent $A$ and acetonitrile was eluent $\mathrm{B}$. The injection volume was $100 \mu \mathrm{l}$ and the flow rate was $1 \mathrm{ml} / \mathrm{min}$. The gradient was applied as mentioned by Ali $\boldsymbol{e t} \boldsymbol{a l}$. (2018) and the detection wavelength was 280 $\mathrm{nm}$.

Determination of hydrolysates molecular weight using SDS-PAGE technique

Sodium dodecyl sulfate-polyacrylamide gel electrophoresis (SDS-PAGE) according to Laemmli (1970) was used to determine the molecular weight of hydrolysates. FB protein and hydrolysates were denaturized by heating at $95^{\circ} \mathrm{C}$ for five minutes in SDS buffer $(0.0625$ $\mathrm{mol} / \mathrm{l}$ Tris-HCl buffer (pH 6.8) with 5\% 2mercaptoethanol, $0.002 \%$ bromophenol blue, $10 \%$ glycerol and $2 \%$ SDS). The gel was immersed in a Coomassie blue solution for two hours followed by a discoloration solution 
(water/methanol/acetic acid, 5.2/4/0.8, $V / V / V$ ) for 12 hr., Sigma Marker TM Low Range of 14$96 \mathrm{KDa}$ molecular range was utilized as a standard. Quantity One Software (Bio-Rad Laboratories, Italy) was used to estimate the molecular weight and intensity of protein band.

Determination of hydrolysates molecular weight using MALDI-TOF MS technique

Matrix assisted laser desorption/ionizationtime of flight mass spectrometry (MALDI- TOF MS) technique based on (Perkins et al., 1999; Ali et al., 2013) was used to determine the molecular weight of hydrolysates. One milligram of native $\mathrm{FB}$ protein and hydrolysates were dissolved in one $\mathrm{ml}$ of $0.1 \%$ trifluoroacetic acid/ acetonitrile $(50 \%, V / V)$. Briefly, $0.5 \mu \mathrm{l}$ of each solution was transported on the MALDI plate and covered with $0.5 \mu \mathrm{l}$ DHAP matrix, and left to dry at room temperature. After crystallization of the sample, measurements were achieved on AUTOFLEX-III LRF200-CID, equipped with Smartbeam-Laser 200 (Bruker Daltonik GmbH, Germany) and the molecular weight of hydrolysates was estimated using the Bruker Daltonics Flex Analysis software.

Determination of antioxidant activity of hydrolysates by TEAC assay

Antioxidant activities of native FB protein and hydrolysates were tested by trolox equivalent antioxidant capacity assay (TEAC) as described by Ali and Elsharkawy (2018), using a Pharmacia Biotech spectrophotometer, England. The results are calculated as $\mu \mathrm{M} \mathrm{TE} / \mathrm{mg}$ protein.

\section{Statistical Analysis}

The obtained data were statistically analyzed using SPSS software version 18. Values of P $\leq$ 0.05 was considered statistically significant (Kumar et al., 2016; Ali and Elsebaie, 2018).

\section{RESULTS AND DISCUSSION}

\section{Chemical Characteristics of Faba Beans}

The chemical composition of FB flour was determined and the obtained results are presented in Table 1. Results indicated that the flour contained 13.32, 37.33, 3.00, 7.81, 2.97 and $48.89 \%$, for moisture, protein, crude fat, crude fiber, ash and available carbohydrates, respectively. Concerning the crude protein content, results disclose that the FB flour contained high amount of crude protein. The value of protein is lower than the findings values obtained previous (Haciseferogullari et al., 2003; Alghamdi, 2009; Hendawey and Younes, 2013). They reported that, the content of protein greatly varied according to faba bean cultivars. Moreover, these variations may be also related to the genetic, fertilization, and environmental factors. On the other hand, it is in the line with the results of Musallam et al. (2004), Hossain and Mortuza (2006) and Kumar et al. (2015). Therefore, FB protein can be used as protein supplement to cereal based foods or can provide a good protein source to produce weaning foods of high nutritive value. Moreover, it could contribute effectively to alleviate the protein malnutrition problem in the developing countries. The percentage of moisture, fat, fiber, and carbohydrates of different cultivars of FB was in a range (7.05 to 8.18), (1.5 to 2.20$)$, (4.61 to 6.91$)$, and (42.2 to 47.3$)$, respectively (Alghamdi, 2009; Hendawey and Younes, 2013).

\section{Solubility of Faba bean Protein Compared to B-Lg}

The solubility is consider one of the main functional properties of protein and is very important for food products. The solubility of FB protein, at different $\mathrm{pH}$ values, compared to $\beta-\mathrm{Lg}$ was measured and the results are shown in Fig. 1. The solubility of $\mathrm{FB}$ protein at $\mathrm{pH} 2$ to 9 was significantly lower than $\beta$ - Lg especially at $\mathrm{pH}$ between 3 and 6 , where it ranged from 53.5 to $58.8 \%$ for $\mathrm{FB}$ protein while, it ranged from 83.2 to $94.1 \%$ for $\beta-\mathrm{Lg}$. Results also showed that the solubility was higher at $\mathrm{pH}$ (7 to 9$)$ where, the values were ranged from 81.3 to $88.1 \%$ but still lower than $\beta-\mathrm{Lg}$ protein.

\section{Emulsifying Properties of Faba Bean Protein Compared to B-Lg Protein}

\section{Oil droplets size}

Faba bean protein was used as emulsifier and the emulsifying properties measured directly after the emulsification and compared with $\beta-\mathrm{Lg}$ protein (Fig. 2). The results of $10^{\text {th }}$ percentile of 
Table 1. Chemical composition (\% on dry weight basis) of faba bean flour

\begin{tabular}{ccccccc}
\hline Constituents & Moisture & Protein & Crude fat & Crude fiber & Ash & Available carbohydrates \\
\hline $\mathbf{( \% )}$ & $13.32 \pm 0.3$ & $37.33 \pm 8.67$ & $3.00 \pm 0.03$ & $7.81 \pm 0.13$ & $2.97 \pm 0.65$ & $48.89 \pm 8.25$ \\
\hline
\end{tabular}

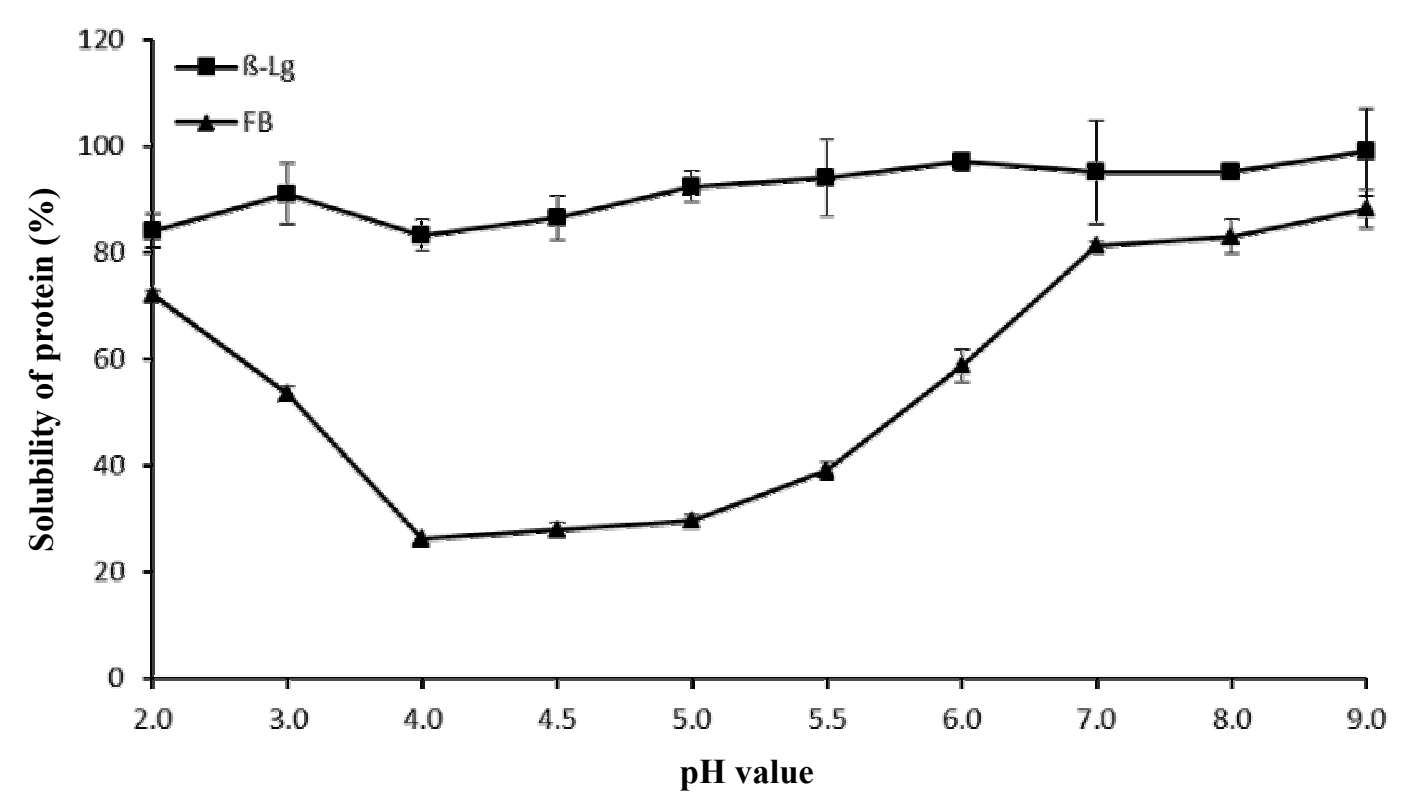

Fig. 1. Solubility of faba protein at different $\mathrm{pH}$ values compared to $\boldsymbol{\beta}-\mathrm{Lg}$ Where: B-Lg, Beta-Lactoglobulin and FB, Faba bean protein

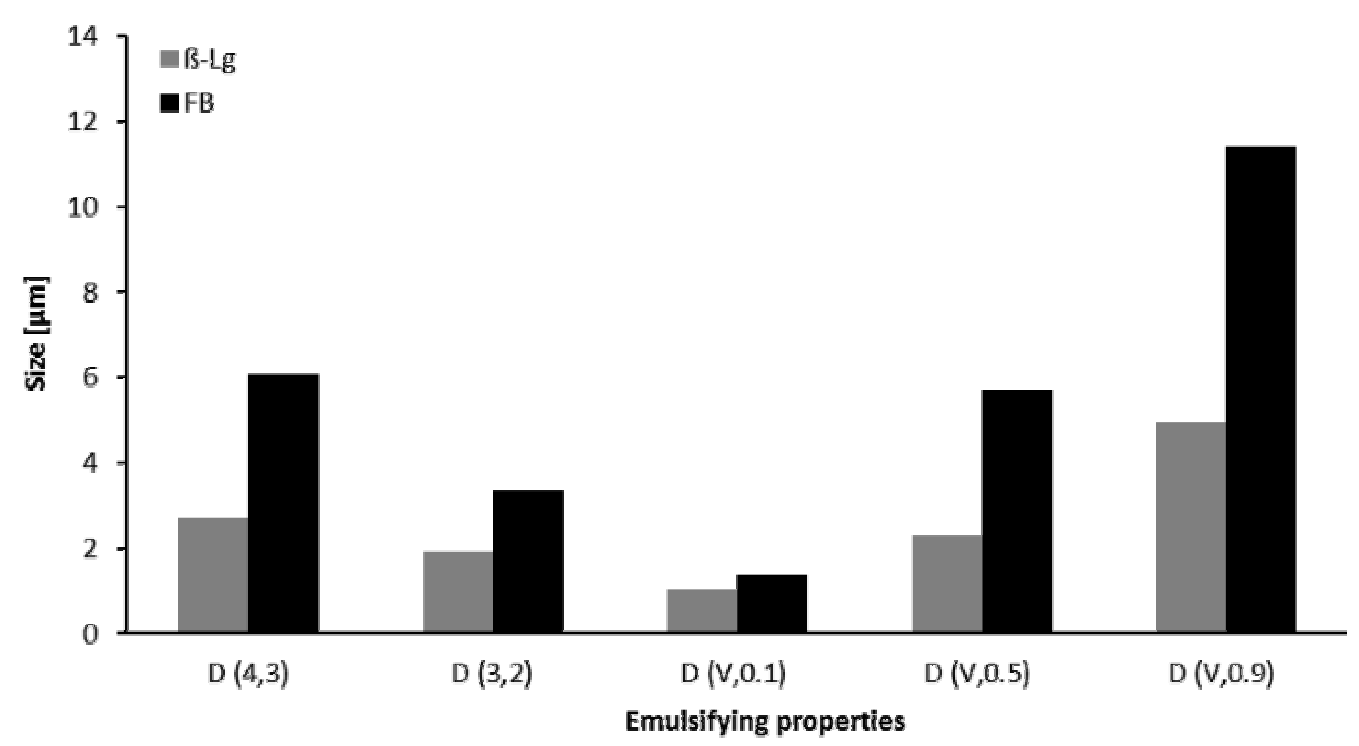

Fig. 2. Oil droplets size of emulsions prepared with faba bean protein compared to B-Lg Where: B-Lg, Beta-Lactoglobulin and FB, Faba bean proteins. 
particles size D (v, 0.1) showed slight differences between emulsions of FB and $\beta-L g$ proteins. In contrast, significant differences were reported between them in the $50^{\text {th }}$ percentile of particles size $\mathrm{D}(\mathrm{V}, 0.5)$ and $90^{\text {th }}$ percentile of the particle size $(\mathrm{V}, 0.9)$. Moreover, it was observed from Fig. 2 that, significant differences $(\mathrm{p} \leq 0.05)$ were detected between the FB and $\beta-\operatorname{Lg}$ emulsions in terms of oil droplet size which shown as volume weighted mean of oil droplet size D $(4,3)$ and surface weighted mean diameter of oil droplet D $(3,2)$, where the values of $D(4,3)$ were 2.71 and $6.08 \mu \mathrm{m}$ while, the values of $\mathrm{D}(3,2)$ were 1.93 and $3.34 \mu \mathrm{m}$ for emulsions prepared with FB and $\beta-L g$ proteins, respectively.

The large size of droplets in emulsion produced using FB protein may be related to its solubility. These results are interesting with the results in Fig. 1, also with stability of emulsion results in Fig. 3.

\section{Stability of emulsions against creaming}

The stability of emulsion is considered one of the main parameter in the food emulsion industry. It refers to the ability of an emulsion to prevent droplet creaming, coalescence, and flocculation. The emulsions, prepared with FB and $\beta-L g$ proteins, were centrifuged at $3000 \mathrm{rpm}$ to form serum layer. Then, the creaming stability of emulsions was studied as the turbidity of emulsions at $500 \mathrm{~nm}$ and the results are presented in Fig. 3. The results exposed that, at the whole time of the experiment $\beta-\mathrm{Lg}$ emulsion was very stable compared to FB protein emulsion, where it did not exposure any creaming part till $65 \mathrm{~min}$ centrifugation. In contrast, the emulsion prepared using FB protein showed slowly decrease in the stability at the first $25 \mathrm{~min}$ followed by intensively decrease at the last 40 min centrifugation.

The low stability of emulsion which emulsified with FB protein may be related to low solubility of protein and the large oil droplets size, as mentioned above in Figs. 1 and 2. The low solubility of protein causes the decrease in the amount of protein at the oil -water interface, which is one of the most important reason for unstable emulsions, where a sufficient amount of protein is fixed to cover oil droplet completely to form more stable emulsion (Aewsiri et al., 2009).

\section{Characterization of Faba Protein Hydrolysates}

\section{Degree of hydrolysis}

When producing hydrolyzed protein, it is important to measure degree of hydrolysis (DH), using the change in protein content, and study the efficiency of protein hydrolysis reaction. Degree of FB protein hydrolysis was calculated for different hydrolysis times, starting from 0 min up to $180 \mathrm{~min}$ and the obtained results are illustrated in Fig. 4. The results indicated that with increasing the hydrolysis time from $0 \mathrm{~min}$ to the first $5 \mathrm{~min}$, the hydrolysis of protein at both $\mathrm{pH}$ (1.5 and 3) was intensively increased. The degree of hydrolysis after about 10 min was not so much. Then, increasing the hydrolysis time for longer periods strongly affected the degree of hydrolysis. As shown also in Fig. 4, the degree of hydrolysis at $\mathrm{pH} 1.5$ was higher than that at $\mathrm{pH} 3$, where the values increased from $0 \%$ at $0 \mathrm{~min}$ to $87.3 \%$ after $180 \mathrm{~min}$ incubation at $\mathrm{pH} 1.5$, while at $\mathrm{pH} 3$ the values were increased from $0 \%$ to $67.4 \%$ when hydrolysis was run from 0 to $180 \mathrm{~min}$. The same trend was observed during the hydrolysis of rapeseed protein isolates, whey protein, red tilapia fish protein and rice bran protein concentrate using alcalase, chymotrypsin, flavourzyme, neutrase thermolysin, protamex, and papain enzymes (Chabanon et al., 2007; Karamac and Rybarczyk, 2008; Dryakova' et al., 2010; Daud et al., 2013; Wisuthiphaet et al., 2015; Ahmadifard et al., 2016). Finally, it could be summarize that, the $\mathrm{DH}$ of protein is dependent on nature of the protein and the hydrolysis conditions, particular $\mathrm{pH}$ and time.

\section{The change in the content of free amino groups}

Fig. 5 represents the effect of hydrolysis time and $\mathrm{pH}$ on the content of free amino groups of FB protein. Results presented in the Figure clearly show that the percentage of free amino groups was increased for both $\mathrm{pH}$ with increasing the hydrolysis time. As seen from the obtained results, the percentage of free amino groups was $43.4 \%$ after first 5 min of hydrolysis at $\mathrm{pH} 3$ and gradually increased by increasing hydrolysis time to reach $134.8 \%$ after $180 \mathrm{~min}$ of hydrolysis, while at $\mathrm{pH} 1.5$ it was $30.5 \%$ after $5 \mathrm{~min}$ of hydrolysis and gradually 
Zagazig J. Agric. Res., Vol. 46 No. (1) 2019

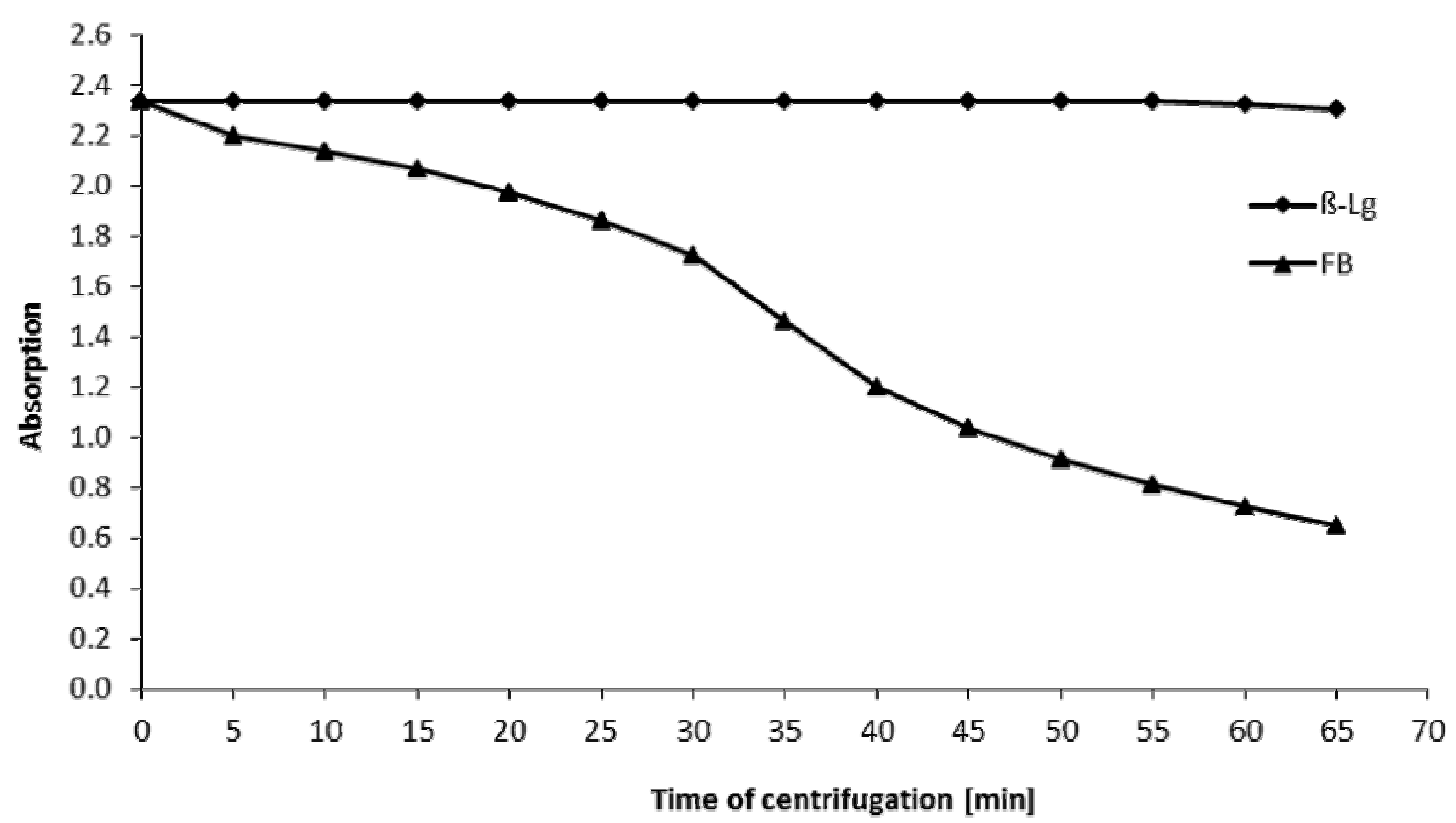

Fig. 3. Stability of emulsions prepared using faba and B-Lg proteins against creaming Where: $\beta$-Lg, Beta-Lactoglobulin and FB, Faba bean proteins

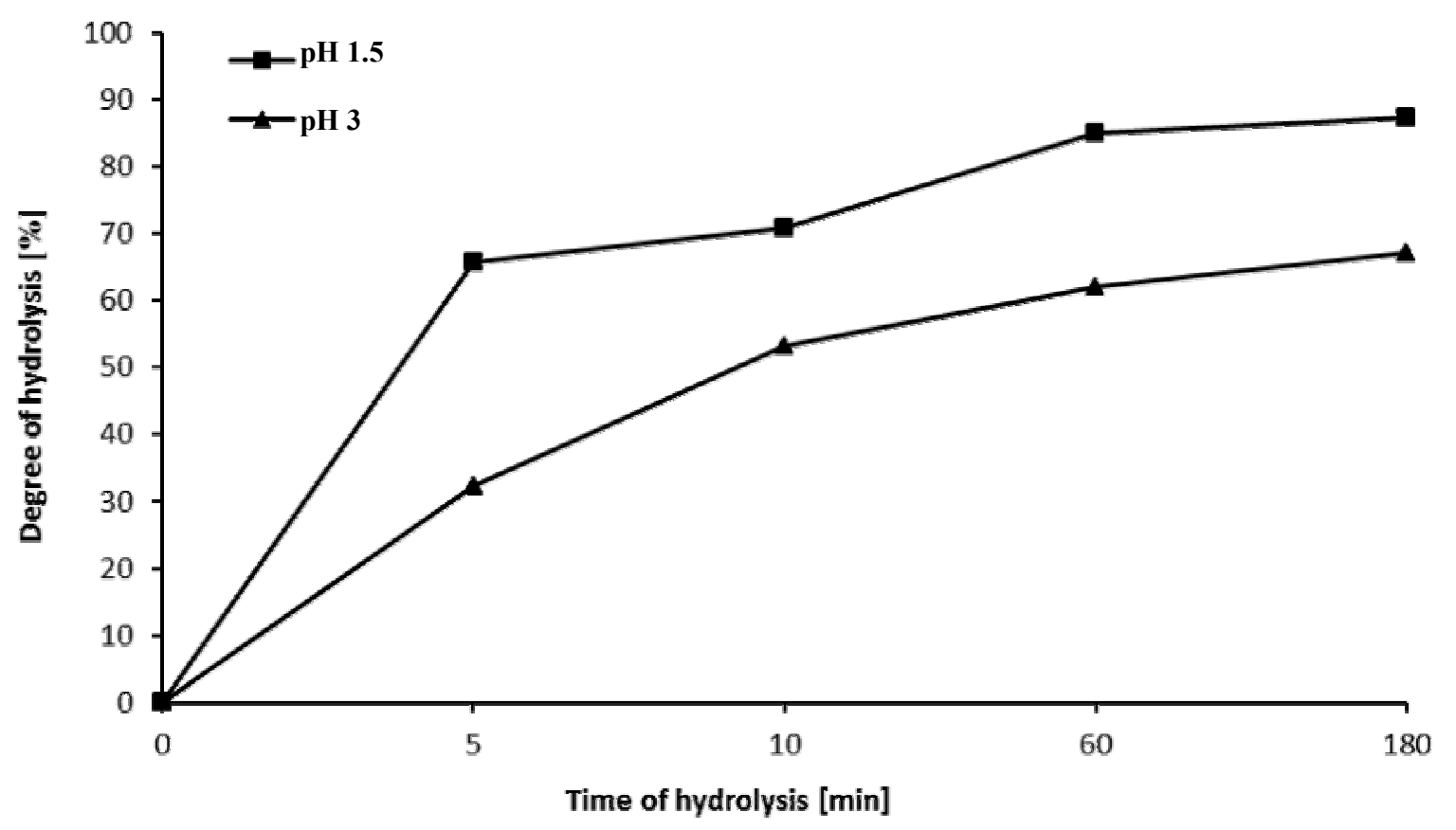

Fig. 4. Degree of hydrolysis (\%) of faba bean protein with pepsin at two pH values for different times 


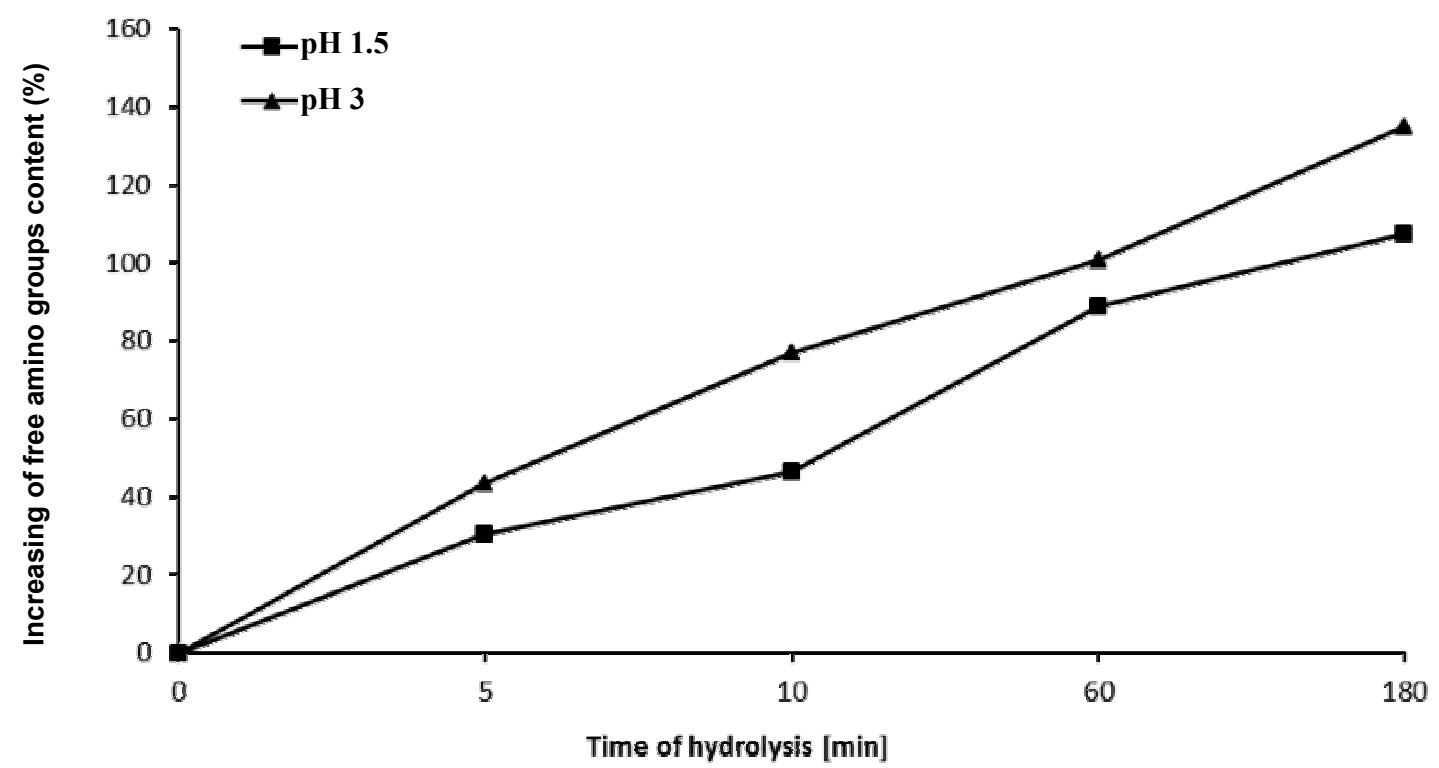

Fig. 5. Effect of enzymatic hydrolysis of faba bean protein at two $\mathrm{pH}$ values for different times on free amino groups content

increased to reach $107.4 \%$ after $180 \mathrm{~min}$ of hydrolysis. The results confirm that, the enzymatic hydrolysis of FB protein showed a positive relationship between the content of free amino groups and the hydrolysis time.

\section{The change in protein content using RP- HPLC method}

The change in native FB protein content, after incubation with pepsin at $\mathrm{pH} 1.5$ and 3 for $0,5,10,60,180 \mathrm{~min}$, was analyzed by RPHPLC (Fig. 6). The results present in the Figure showed that the amount of protein was gradually decreased with increasing hydrolysis time. Hydrolysis at $\mathrm{pH} 1.5$ exposed the highest decrease in area under curve where, the value was $3959744 \mathrm{mAU} / \mathrm{s}$ at 0 time and 847243 $\mathrm{mAU} / \mathrm{s}$ after $180 \mathrm{~min}, \sim 4.7$ fold. On the other hand, it recorded $1887093 \mathrm{mAU} / \mathrm{s}$ after incubation for $180 \mathrm{~min}$ at $\mathrm{pH} 3, \sim 2.1$ fold.

\section{Characterization of Molecular Weights of Hydrolysates}

\section{Molecular weight distribution using SDS- PAGE}

The storage protein of FB belongs to $11 \mathrm{~S}$ class proteins (Ali et al., 2012). To study the effect of pepsin on protein breakdown in FB protein, SDS-PAGE was performed on the hydrolysates after enzymatic hydrolysis at two different $\mathrm{pH}$ values (1.5 and 3) for $0,5,10,60$, and $180 \mathrm{~min}$. The results are shown in Figs. 7A and $\mathrm{B}$ and Tables 2 and 3, where the line 1 in each figure shows the molecular weight of marker, line 2 the starting material, and lines 3 to 6 showed the hydrolysates obtained after incubation with pepsin at $\mathrm{pH} 1.5$ and 3 for 5,10 , 60 and $180 \mathrm{~min}$. SDS-PAGE separated extractable proteins into subunits and polypeptides. The SDS-electrophoretic profile of faba protein (Figs. 7A and B, line 2) contained 15 bands with molecular weight range between 11 and $98 \mathrm{KDa}$. According to El-Saber (2010), the FB protein was separated using SDS-PAGE into 28 bands with a range of molecular weight range from 10 to $205 \mathrm{KDa}$, while Hendawey and Younes (2013) used the same technique to separate FB protein from different cultivars and they found around 32 bands with a range of molecular weight range from 14 to $95 \mathrm{KDa}$. As shown in Tables 2 and 3, the more intensive bands in FB protein at zero time are presented at molecular mass 98, 92, 71, 58, 47, 38, 34, 25, 22 and $21 \mathrm{KDa}$. These masses were identified as subunits of conglycinin, acidic and basic subunits of glycinin and lipoxygenase (Barac et al., 2006) while, Wu et al. (1998) reported that the SDS-PAGE patterns of soya protein isolate contained five major bands; three of them were 


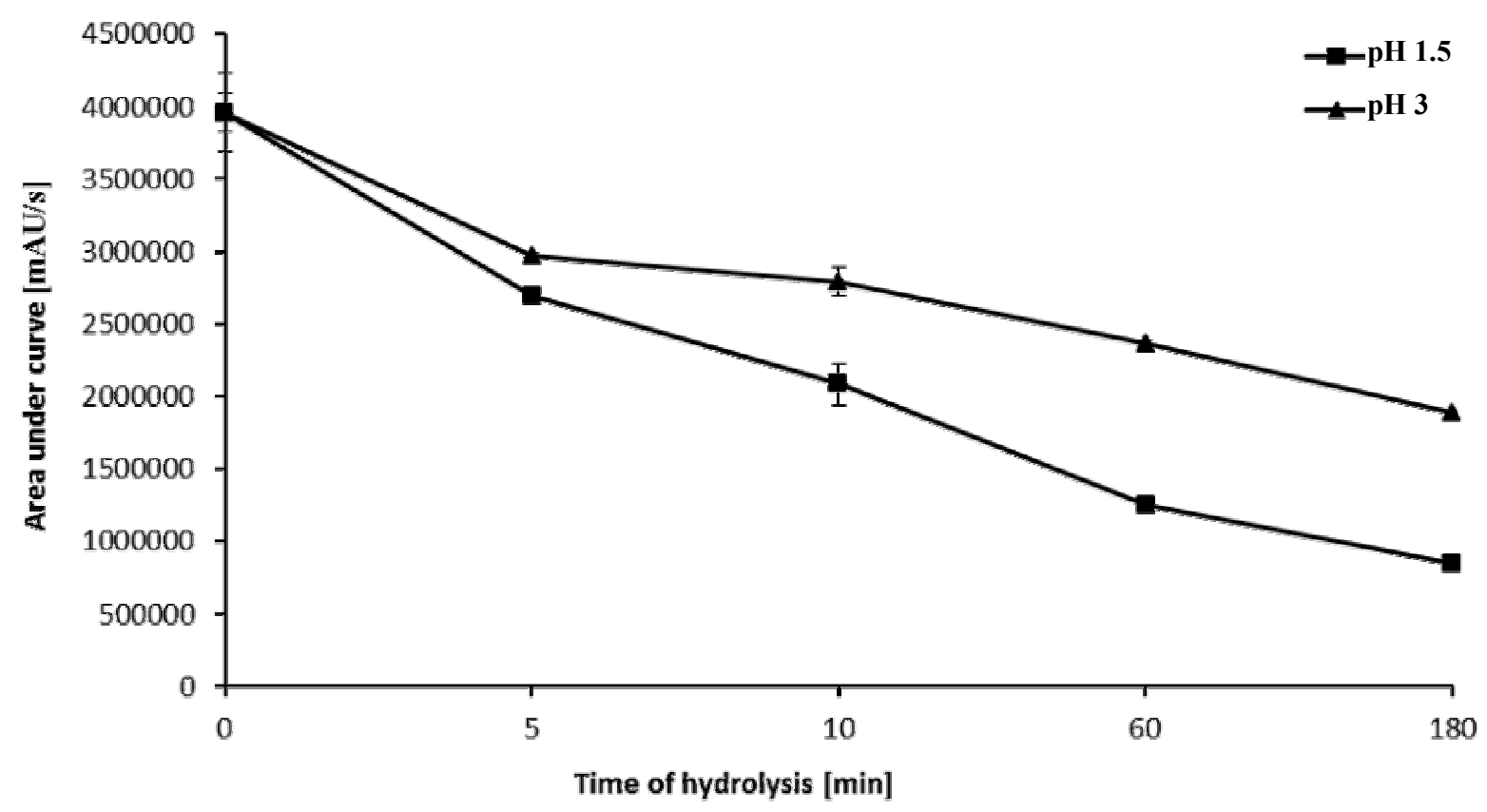

Fig. 6. Effect of enzymatic hydrolysis of faba bean protein at two $\mathrm{pH}$ values for different times on the content of protein using RP-HPLC
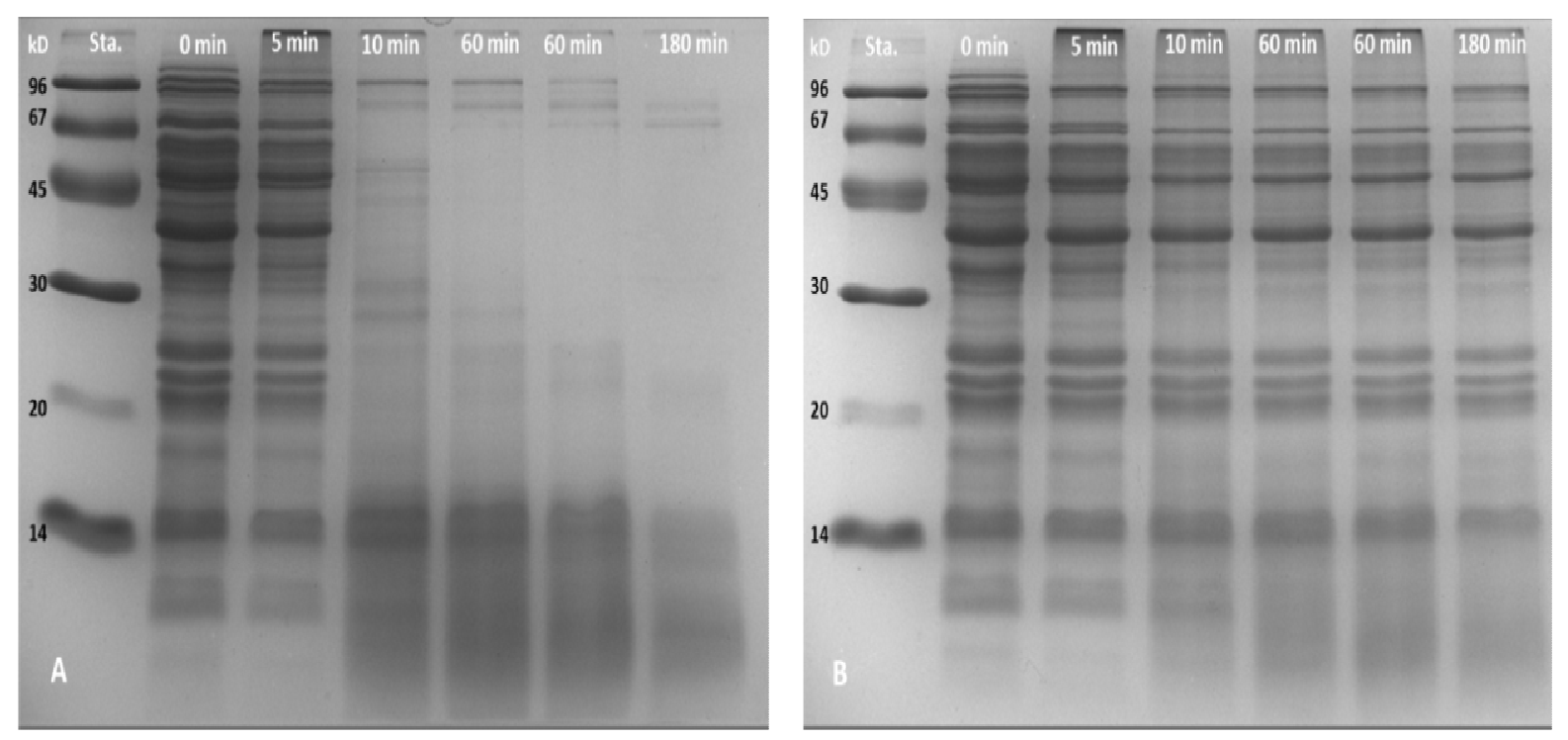

Fig. 7. SDS-PAGE profiles of faba bean protein after hydrolysis at $\mathrm{pH} 1.5$ (A) and $\mathrm{pH} 3$ (B) for different times. Sta, molecular weights of marker 
Table 2. Molecular weights (KDa) and intensity of bands of faba bean protein after hydrolysis at pH 1.5 for different times

\begin{tabular}{cccccc}
\hline Mol. Wt. (KDa) & \multicolumn{5}{c}{ Intensity of bands } \\
\cline { 2 - 6 } & \multicolumn{5}{c}{ Time of hydrolysis } \\
\cline { 2 - 6 } & $\mathbf{0 ~ m i n}$ & $\mathbf{5}$ min & $\mathbf{1 0}$ min & $\mathbf{6 0}$ min & $\mathbf{1 8 0}$ min \\
\hline 98 & 3065 & 2907 & 2282 & 1546 & $\mathrm{X}$ \\
92 & 3103 & 2808 & $\mathrm{X}$ & $\mathrm{X}$ & $\mathrm{X}$ \\
80 & $\mathrm{X}$ & $\mathrm{X}$ & 1861 & 1581 & 1361 \\
71 & 3083 & 2822 & $\mathrm{X}$ & $\mathrm{X}$ & $\mathrm{X}$ \\
69 & $\mathrm{X}$ & $\mathrm{X}$ & $\mathrm{X}$ & 1416 & 1474 \\
58 & 3085 & 2875 & $\mathrm{X}$ & $\mathrm{X}$ & $\mathrm{X}$ \\
47 & 3242 & 3076 & $\mathrm{X}$ & $\mathrm{X}$ & $\mathrm{X}$ \\
38 & 3275 & 3094 & $\mathrm{X}$ & $\mathrm{X}$ & $\mathrm{X}$ \\
34 & 3020 & 2695 & $\mathrm{X}$ & $\mathrm{X}$ & $\mathrm{X}$ \\
32 & 2708 & 2423 & $\mathrm{X}$ & $\mathrm{X}$ & $\mathrm{X}$ \\
25 & 2863 & 2552 & 1982 & 1404 & $\mathrm{X}$ \\
22 & 2839 & 2541 & $\mathrm{X}$ & 1466 & $\mathrm{X}$ \\
21 & 2866 & 2508 & $\mathrm{X}$ & $\mathrm{X}$ & $\mathrm{X}$ \\
18 & 2427 & 2115 & $\mathrm{X}$ & $\mathrm{X}$ & $\mathrm{X}$ \\
14 & 2792 & 2495 & 2733 & 2383 & 1919 \\
12 & 2263 & 2057 & 2454 & 2325 & 1938 \\
11 & 2299 & 2068 & 2493 & 2377 & 2077 \\
10 & $\mathrm{x}$ & $\mathrm{x}$ & 2409 & 2457 & 2103 \\
9 & $\mathrm{x}$ & $\mathrm{x}$ & $\mathrm{x}$ & 2246 & 2021 \\
\hline
\end{tabular}

$\mathrm{X}$ means the band not detected

Table 3. Molecular weights (KDa) and intensity of bands of faba bean protein after hydrolysis at $\mathrm{pH} 3$ for different times

\begin{tabular}{cccccc}
\hline Mol. Wt. & \multicolumn{5}{c}{ Intensity of bands } \\
\cline { 2 - 6 } (kDa) & \multicolumn{5}{c}{ Time of hydrolysis } \\
\cline { 2 - 6 } & $\mathbf{0 ~ m i n}$ & $\mathbf{5}$ min & $\mathbf{1 0}$ min & $\mathbf{6 0}$ min & $\mathbf{1 8 0}$ min \\
\hline 98 & 2918 & 2870 & 2685 & 2491 & 2188 \\
92 & 2915 & 2452 & 2355 & $X$ & 1825 \\
71 & 2850 & 2604 & 2380 & 2333 & 2222 \\
58 & 2847 & 2711 & 2422 & 2297 & 2059 \\
47 & 3050 & 2937 & 2675 & 2683 & 2605 \\
38 & 3094 & 3009 & 2805 & 2756 & 2630 \\
34 & 2820 & 2509 & 2086 & 1864 & 1804 \\
32 & 2413 & 2145 & 1785 & 1583 & 1492 \\
25 & 2574 & 2380 & 2066 & 1931 & 1838 \\
22 & 2555 & 2366 & 2135 & 1958 & 1879 \\
21 & 2575 & 2335 & 2186 & 2041 & 1918 \\
18 & 1997 & 1750 & 1654 & 1505 & 1382 \\
14 & 2420 & 2228 & 2215 & 2109 & 1849 \\
12 & 1774 & 1665 & $x$ & $X$ & X \\
11 & 1875 & 1713 & $x$ & $X$ & X \\
10 & $x$ & $x$ & 1783 & 1845 & 1638 \\
9 & $x$ & $x$ & $x$ & 1766 & 1520 \\
\hline
\end{tabular}

$\mathrm{X}$ means the band not detected 
identified as $7 \mathrm{~S}$ globulin, and two as $11 \mathrm{~S}$ globulin, in addition to minor bands were identified as subunits of $11 \mathrm{~S}$ globulin, and lipoxygenase. Results presented in Fig. 7A and illustrated in Table 2 clearly indicate that the intensity of bands produced at $\mathrm{pH} 1.5$ was gradually decreased and many bands were disappeared. Moreover, some new bands represent as polypeptides were appeared compared to the hydrolysis at $\mathrm{pH} 3$ which showed also decrease in the intensity of bands but only two bands were vanished (12 and $11 \mathrm{KDa}$ ) and some of new ones appeared (Fig. 7B and Table 3). FB protein showed many protein bands not completely digested by pepsin enzyme at $\mathrm{pH} 3$ compared to at $\mathrm{pH}$ 1.5. The bands corresponding to non-hydrolyzed protein in FB were persisted till 180 min of hydrolysis at $\mathrm{pH} 3$ while at $\mathrm{pH}$ 1.5 they were only persisted till $5 \mathrm{~min}$, the bands exhibited until 5 min but then disappeared.

\section{Molecular weight distribution using MALDI-TOF MS}

The FB protein hydrolysates produced by pepsin at $\mathrm{pH} 1.5$ and 3 were analysed with MALDI-TOF MS to identify the molecular weight of peptides (Figs. $8 \mathrm{~A}$ and $\mathrm{B}$ ), which is an important parameter reflecting the proteins hydrolysis (Li et al., 2008). From the results of SDS-PAGE, the bands with molecular weight lower than $9 \mathrm{KDa}$ cannot be identified so, these molecules were subject to MALDI-TOF MS. According to the literature, this is the first paper used this technique to identify the peptides, and the results are shown in Figs 8A and B. Results in these Figures showed the molecular weight of peptides between 500 and $4000 \mathrm{Da}$, where FB protein hydrolyzed at $\mathrm{pH} 1.5$ for 5 min showed only one peptide with $\mathrm{m} / \mathrm{z} 542$ compared to two peptides with $\mathrm{m} / \mathrm{z} 550$ and 638 at $\mathrm{pH} 3$. In general, results in Figures clearly indicate that FB protein was hydrolyzed well with $1 \%$ pepsin at $\mathrm{pH} 1.5$ compared to $\mathrm{pH} 3$, where the number of peptides was more, in addition the intensity of peaks was higher. On the other hand, pepsin incubated at $\mathrm{pH} 3$ did not hydrolyze FB protein well even after $180 \mathrm{~min}$ of incubation. These results support the results of SDS-PAGE, degree of hydrolysis and RP-HPLC in the present study.

\section{Antioxidant activity of hydrolysates by TEAC assay}

The antioxidant activities of lyophilized hydrolysates of $\mathrm{FB}$ protein ( $\mu \mathrm{M} \mathrm{TE} / \mathrm{mg}$ ) were compared to each other and with that of native FB protein based on free radical scavenging capacity and the results are shown in Fig. 9. As shown in the Figure, hydrolysates by pepsin at $\mathrm{pH} 3$ resulted in a slight higher antioxidant activity than hydrolysates by pepsin at $\mathrm{pH} 1.5$. The antioxidant activity was higher at first $5 \mathrm{~min}$ then increased with increasing the time of hydrolysis. The value of antioxidant activity was $0.052 \mu \mathrm{M} \mathrm{TE} / \mathrm{mg}$ protein for native protein, then the values increased notably with all tested hydrolysates, from 0.228 to 0.347 and from 0.213 to $0.337 \mu \mathrm{M} \mathrm{TE} / \mathrm{mg}$ protein after incubation from 5 to $180 \mathrm{~min}$ at $\mathrm{pH} 3$ and 1.5, respectively. As reported by Graszkiewicz et al. (2007) and Lin et al. (2011), lysozyme and cystatin, and whole egg white proteins hydrolyzed with trypsin and alcalase showed a strong antioxidant activity. Also, hydrolysis of the whey protein, soya sauce lees, dairy protein concentrates, skim milk proteins and fish meat of red Tilapia with different enzymes increased the antioxidant activity (Dryakova' et al., 2010; Yang et al., 2011; Conway et al., 2012; Daud et al., 2013).

High degree of hydrolysis thus means high content of released amino groups and it should presumably show also good antioxidant activity in hydrolysates (Dryakova' et al., 2010). Nevertheless, the antioxidant activity of hydrolysates was not found to be directly attributed to $\mathrm{DH}$, suggesting that the activity is inherent to specific amino acid sequence. The results in the present work indicated that enzymatic hydrolysis using pepsin significantly $(p \leq 0.05)$ improved the antioxidant potential of FB protein. A strong correlation between $\mathrm{ABTS}^{+}$ scavenging activity and $\mathrm{DH}$ of pepsin hydrolysates of FB protein was observed. The proteins owe their antioxidant activity to their constituent amino acids such as aromatic, sulfur containing and basic amino acids which are capable to donate protons to free radicals (Je et al., 2005; Rajapakse et al., 2005). It is possible that unfolding of the protein structure showing amino acids previously absent inside the native protein structure, causing an increase in the antioxidant activity so, it suggested that steric structure and molecular weight of peptides might exert more important role in scavenging DPPH radicals than the content of antioxidant amino acids (Young et al., 2011). 

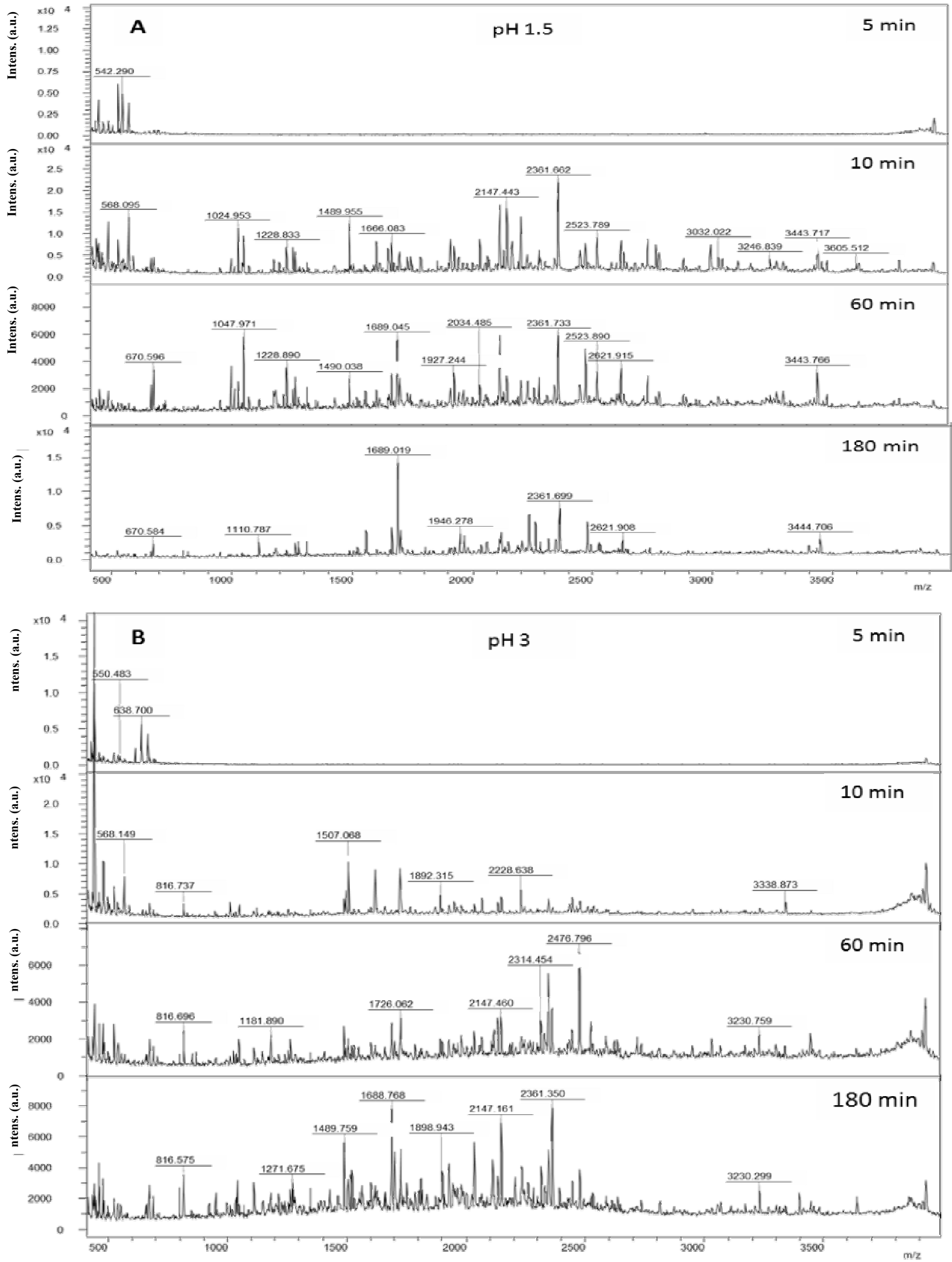

Fig. 8. Molecular weights (KDa) of faba bean protein hydrolysates after hydrolysis at pH 1.5 (A) and $\mathrm{pH} 3$ (B) for different times 


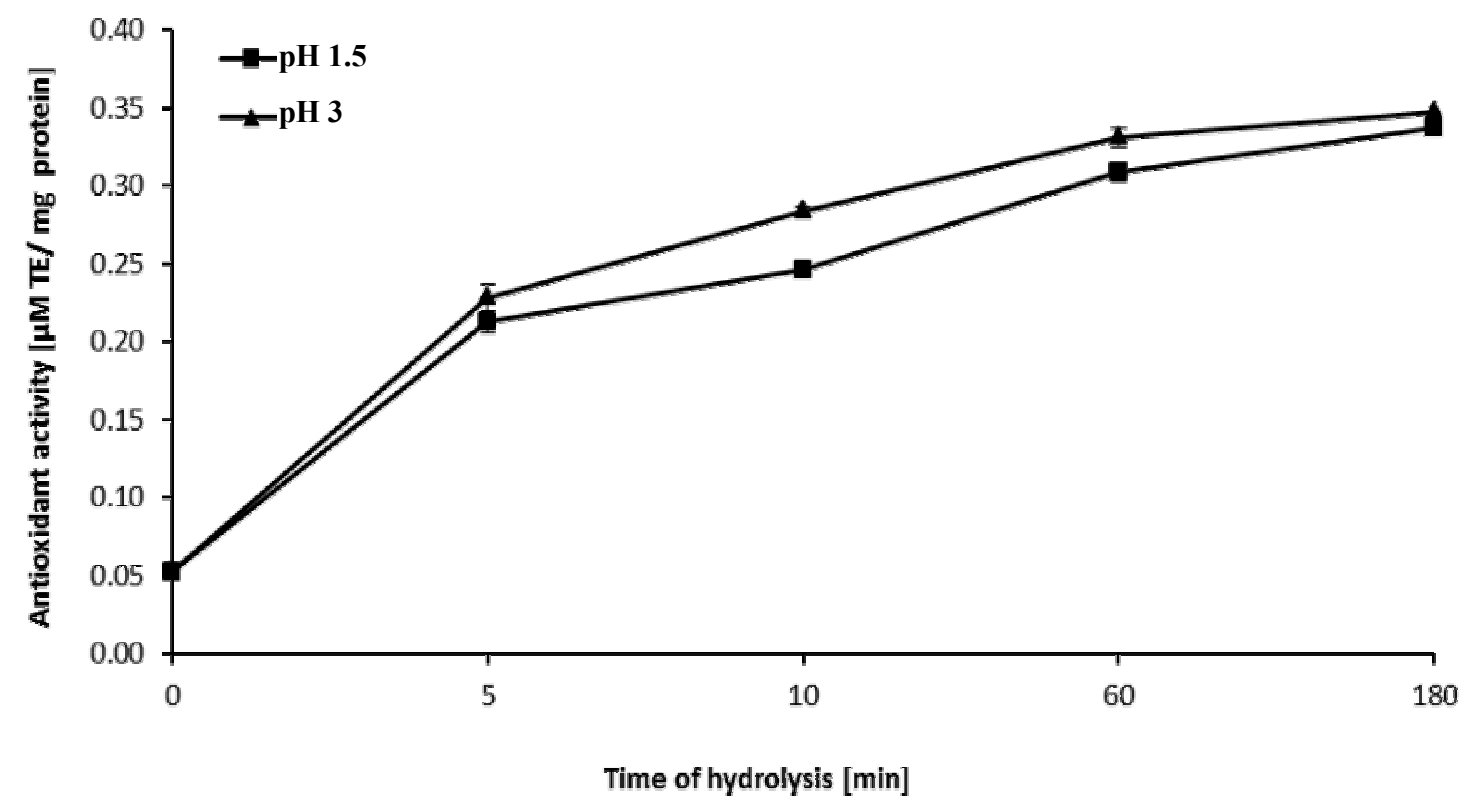

Fig. 9. Effect of enzymatic hydrolysis of faba bean protein at two $\mathrm{pH}$ values for different times on the antioxidant activity with TEAC assay

\section{Conclusion}

This study thus provides useful information for increasing the commercial value of faba bean protein as a multifunctional ingredient. It could be concluded that, the functional properties of native FB protein was lower than the properties of $\beta-L g$ protein. These properties were improved using enzymatic hydrolysis process. FB protein could be hydrolyze by pepsin at $\mathrm{pH} 1.5$. Hydrolysates produced at $\mathrm{pH} 1.5$ were higher than which at $\mathrm{pH} 3$. Also, pepsin may give higher antioxidant peptides after only $5 \mathrm{~min}$ incubation. Finally, test model systems closer to real food processing conditions would be helpful to evaluate whether plant protein hydrolysates could be a viable alternative for other functional protein sources. Moreover, the other functional properties of FB hydrolysates will be study in our future work.

\section{Acknowledgements}

The author acknowledges the Egyptian government for financial support and Prof. Rawel (Food Chemistry Department, Institute of Human Nutrition, Potsdam University, Germany) for working in his laboratory to achieve this work.

\section{REFERENCES}

Adler-Nissen, J. (1979). Determination of the degree of hydrolysis of food protein hydrolysates by trinitrobenzenesulfonic acid. J. Agric. Food Chem., 27: 1256-1262.

Aewsiri, T., S. Benjakul, W. Visessanguan, J.-B. Eun, P.A. Wierenga and H. Gruppen (2009). Antioxidative activity and emulsifying properties of cuttlefish skin gelatin modified by oxidised phenolic compounds. Food Chem., 117: 160-168.

Ahmadifard, N., J.H.C. Murueta, A. AbedianKenari, A. Motamedzadegan and H. Jamali (2016). Comparison the effect of three commercial enzymes for enzymatic hydrolysis of two substrates (rice bran protein concentrate and soy-been protein) with SDS-PAGE. J. Food Sci. Technol., 53: 1279-1284.

Alghamdi, S.S. (2009). Chemical Composition of faba bean (Vicia faba L.) genotypes under various water regimes. Pak. J. Nutr., 8: 477482. 
Ali, M. and E. Elsebaie (2018). Milk whey proteins and onion extract powder interactions-antimicrobial and anticancer activities. J. Agroaliment. Proc. Technol., 24: 152-160.

Ali, M. and M.M. Elsharkawy (2018). Characterization of whey protein isolate covalently modified with phenolic compounds-1: Antioxidant and antiviral activities. J. Food and Dairy Sci., Mansoura Univ., 9: 385-393.

Ali, M., T. Homann, M. Khalil, H.-P. Kruse and H. Rawel (2013). Milk whey protein modification by coffee-specific phenolics: effect on structural and functional properties. J. Agric. Food Chem., 61: 6911-6920.

Ali, M., T. Homann, J. Kreisel, M. Khalil, R. Puhlmann, H.-P. Kruse and H. Rawel (2012). Characterization and modeling of the interactions between coffee storage proteins and phenolic compounds. J. Agric. Food Chem., 60: 11601-11608.

Ali, M., J.K. Keppler, T. Coenye and K. Schwarz (2018). Covalent whey protein-rosmarinic acid interactions: a comparison of alkaline and enzymatic modifications on physicochemical, antioxidative, and antibacterial properties. J. Food Sci., 83: 2092-2100.

AOAC (2011). Official Methods of Analysis of AOAC International. $18^{\text {th }}$ Ed., AOAC Int., Gaitherburg, 2590.

Bamdad, F., A.H. Goli and M. Kadivar (2006). Preparation and characterization of proteinous film from lentil (Lens culinaris): Edible film from lentil (Lens culinaris). Food Res. Int., 39: 106-111.

Barac, M.B., S.T. Jovanovic, S.P. Stanojevic and M.B. Pesic (2006). Effect of limited hydrolysis on traditional soy protein concentrate. Sensors, 6: 1087-1101.

Bradford, M.M. (1976). A rapid and sensitive method for the quantitation of microgram quantities of protein utilizing the principle of protein-dye binding. Anal. Biochem., 72: 248-254.
Chabanon, G., I. Chevalot, X. Framboisier, S. Chenu and I. Marc (2007). Hydrolysis of rapeseed protein isolates: Kinetics, characterization and functional properties of hydrolysates. Process Biochem., 42: 14191428.

Chove, B.E., A.S. Grandison and M.J. Lewis (2007). Some functional properties of fractionated soy protein isolates obtained by microfiltration. Food Hydrocoll., 21: 13791388.

Conway, V., S.F. Gauthier and Y. Pouliot (2012). Antioxidant activities of buttermilk proteins, whey proteins, and their enzymatic hydrolysates. J. Agric. Food Chem., 61: 364372.

Daud, N.A., A.S. Babji and S.M. Yusop (2013) Antioxidant Activities of Red Tilapia (Oreochromis niloticus) Protein Hydrolysates as Influenced by Thermolysin and Alcalase. AIP Conf. Proc. AIP.

Dryakova', A., A. Pihlanto, P. Marnila, L. Curda and H.J. Korhonen (2010). Antioxidant properties of whey protein hydrolysates as measured by three methods. Eur. Food Res. Technol., 230: 865-874.

El-Saber, M. (2010) Biochemical Studies on Faba Bean under Rainfed at Maryout Condition. M.Sc. Thesis, Dept. Agric. Biochem., Fac. Agric., Zagazig Univ., Egypt.

El-Fiel, H.E.A., A.H. El-Tinay and E.A.E. Elsheikh (2002). Effect of nutritional status of faba bean (Vicia faba L.) on protein solubility profiles. Food Chem., 76: 219-223.

Fernández-Quintela, A., M. Macarulla, A. Del Barrio and J. Martínez (1997). Composition and functional properties of protein isolates obtained from commercial legumes grown in northern Spain. Plant Foods Hum. Nutr., 51: 331-341.

Graszkiewicz, A., M. Zelazko, T. Trziszka and A. Polanowski (2007). Antioxidative capacity of hydrolysates of hen egg proteins. Pol. J. Food Nutr. Sci., 57: 195-199.

Haciseferogullari, H., H. Gezer, Y. Bahtiyarca and H.O. Menges (2003). Determination of some chemical and physical properties of 
Sakiz faba bean (Vicia faba L. Var. major). J. Food Eng., 60: 475-479.

Hendawey, M.H. and A.M.A. Younes (2013). Biochemical evaluation of some faba bean cultivars under rainfed conditions at ElSheikh Zuwayid. Ann. Agric. Sci., 58 : 183193.

Hossain, M.S. and M.G. Mortuza (2006). Chemical composition of kalimatar, a locally grown strain of faba bean (Vicia faba L.). Pak. J. Biol. Sci., 9: 1817-1822.

Hrckova, M., M. Rusnakova and J. Zemanovic (2002). Enzymatic hydrolysis of defatted soy flour by three different proteases and their effect on the functional properties of resulting protein hydrolysates. Czech J. Food Sci., 20: 7-14.

Hu, M., D.J. Mcclements and E.A. Decker (2003). Lipid oxidation in corn oil-in-water emulsions stabilized by casein, whey protein isolate, and soy protein isolate. J. Agric. Food Chem., 51: 1696-1700.

Je, J.-Y., P.-J. Park and S.-K. Kim (2005). Antioxidant activity of a peptide isolated from Alaska pollack (Theragra chalcogramma) frame protein hydrolysate. Food Res. Int., 38: 45-50.

Karamac, M. and A. Rybarczyk (2008). Chymotryptic hydrolysis of lentil meal proteins and characteristics of the resulting hydrolysates. Pol. J. Food Nutr. Sci., 58: 351-357.

Khalil, M., J. Raila, M. Ali, K.M. Islam, R. Schenk, J.-P. Krause, F.J. Schweigert and H. Rawel (2012). Stability and bioavailability of lutein ester supplements from Tagetes flower prepared under food processing conditions. J. Funct. Foods, 4: 602-610.

Kimura, A., T. Fukuda, M. Zhang, S. Motoyama, N. Maruyama and S. Utsumi (2008). Comparison of physicochemical properties of $7 \mathrm{~S}$ and $11 \mathrm{~S}$ globulins from pea, fava bean, cowpea, and french bean with those of soybeans-french bean 7S globulin exhibits excellent properties. J. Agric. Food Chem., 56: 10273-10279.

Kumar, A., N. Prasad and S. K. Sinha (2015). Nutritional and antinutritional attributes of faba bean (Vicia faba L.) germplasms growing in Bihar, India. Physiol. Mol. Biol. Plants, 21: 159-162.

Kumar, S., H. Ambreen, M.T. Variath, A.R. Rao, M. Agarwal, A. Kumar, S. Goel and A. Jagannath (2016). Utilization of molecular, phenotypic, and geographical diversity to develop compact composite core collection in the oilseed crop, safflower (Carthamus tinctorius L.) through maximization strategy. Front. Plant Sci., 7: 1554.

Laemmli, U.K. (1970). Cleavage of structural proteins during the assembly of the head of bacteriophage T4. Nature, 227: 680-685.

Le Tien, C., C. Vachon, M. Mateescu and M. Lacroix (2001). Milk protein coatings prevent oxidative browning of apples and potatoes. J. Food Sci., 66: 512-516.

Li, Y., B. Jiang, T. Zhang, W. Mu and J. Liu (2008). Antioxidant and free radicalscavenging activities of chickpea protein hydrolysate $(\mathrm{CPH})$. Food Chem., 106: 444450.

Lin, S., Y. Guo, J. Liu, Q. You, Y. Yin and S. Cheng (2011). Optimized enzymatic hydrolysis and pulsed electric field treatment for production of antioxidant peptides from egg white protein. Afr. J. Biotechnol., 10: 1164811657.

Magoda, S.F. and R.M. Gous (2011). Evaluation of dehulled faba bean (Vicia faba cv. Fiord) as a protein source for laying hens. S. Afr. J. Anim. Sci., 41: 87-93.

Morales-De Leon, J.C., N. Vazquezu-Mata, N. Torres, L. Gil-Zenteno and R. Bressani (2007). Preparation and characterization of protein isolate from fresh and hardened beans (Phaseolus vulgaris L.). J. Food Sci., 72: 96102.

Musallam, I.W., G.N. Al-Karaki, K.I. Ereifei, A. Rahman and A.R.M. Tawaha (2004). Chemical composition of faba bean genotypes under rainfed and irrigation conditions. Int. J. Agric. Biol., 6: 359-362.

Penas, E., G. Prestamo and R. Gomez (2004). High pressure and the enzymatic hydrolysis of soybean whey proteins. Food Chem., 85: 641-648. 
Perkins, D.N., D.J.C. Pappin, D.M. Creasy and J.S. Cottrell (1999). Probability-based protein identification by searching sequence databases using mass spectrometry data. Electophoresis, 20: 3551-3567.

Rajapakse, N., E. Mendis, W.-K. Jung, J.-Y. Je and S.-K. Kim (2005). Purification of a radical scavenging peptide from fermented mussel sauce and its antioxidant properties. Food Res. Int., 38: 175-182.

Wimonsiri, L., P. Ritthiruangdej, S. Kasemsumran, N. Therdthai, W. Chanput and Y. Ozaki (2017). Rapid analysis of chemical composition in intact and milled rice cookies using near infrared spectroscopy. J. Near Infrared Spectrosc., 25: 330-337.

Wisuthiphaet, N., S. Kongruang and C. Chamcheun (2015). Production of fish protein hydrolysates by acid and enzymatic hydrolysis. J. Med. and Bioeng., 4.

Wu, W., N. Hettiarachchy and M. Qi (1998). Hydrophobicity, solubility, and emulsifying properties of soy protein peptides prepared by papain modification and ultrafiltration. J. Am. Oil Chem. Soc., 75: 845-850.

Yang, B., H. Yang, J. Li, Z. Li and Y. Jiang (2011). Amino acid composition, molecular weight distribution and antioxidant activity of protein hydrolysates of soy sauce lees. Food Chem., 124: 551-555.

Young, D., R. Tsao and Y. Mine (2011). Nutraceuticals and antioxidant function. functional foods, nutraceuticals, and degenerative disease prevention, 75-112.

الخواص الوظيفية لبروتين الفول البلدى وتأثير التحليل الإنزيمي على نثاطه كمضاد للأكسدة

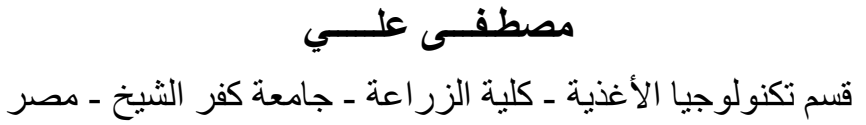

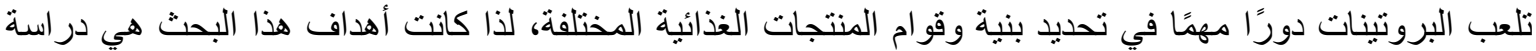

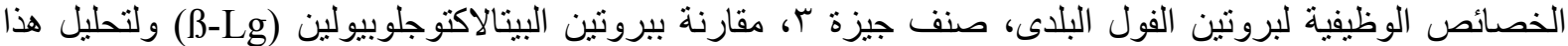

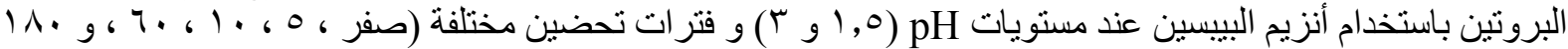

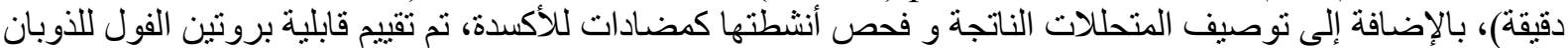

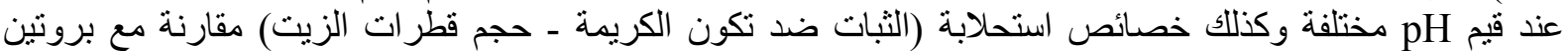

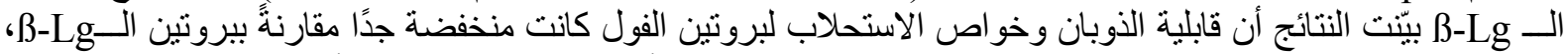

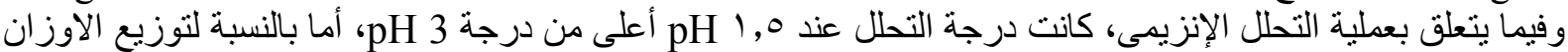
الجزيئية لمتحلات بروتين الفول فكانت في نطاق 9 - 91 كيلو دالتون عند استخدام طريقة SDS-PAGE بينة

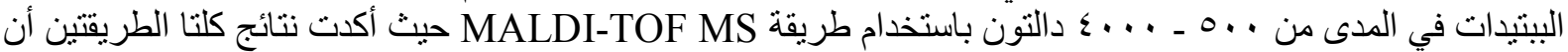

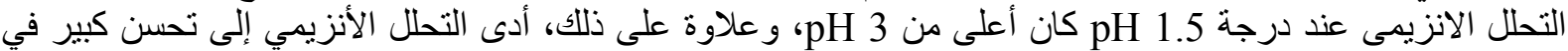

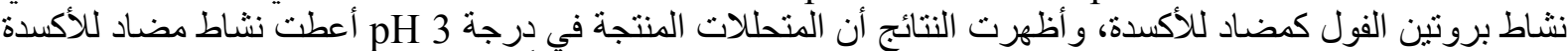

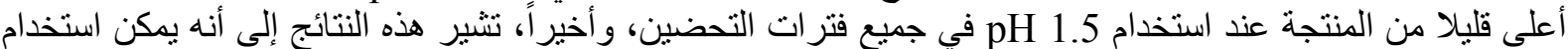
متحلات بروتين الفول في إعداد الأغذية الوظيفية وكضيادات أكسدة طبيعية لمنع عملية الأكسدة في المنتجات الغذائية. 